\title{
TRENDS IN PERINATAL AND NEONATAL MORTALITY IN ENGLAND AND WALES 1960-69
}

\author{
J. G. FRYER AND J. R. ASHFORD \\ Department of Mathematics, University of Exeter
}

The use of perinatal and neonatal mortality rates as indicators of general standards of health and well-being in a community is now widely accepted. In England and Wales, the Annual Reports of the Department of Health have shown a consistent reduction in mortality during the past two decades. Similar trends have been observed in other developed countries, although there are wide variations in the rate at which mortality has fallen in different parts of the world (Hunt and Goldstein, 1961). Indeed, against the background of even greater progress and even lower overall mortality rates in a number of other countries, it is clear that further substantial improvements in England and Wales are both desirable and possible.

It is generally recognized that perinatal and neonatal mortality may result from a wide variety of influences, many of which are inter-related. These vary from genetic and physiological factors on the one hand to the social and economic environment of the mother, not only during the current or previous pregnancies but also throughout the whole of her life, on the other. The availability and quality of medical care is also important, although it is not clear precisely to what extent deficiencies in environmental and biological circumstances may be overcome by purely medical measures.

During recent years, there have been many changes in the basis of the provision of maternity services in England and Wales. The Committee of Enquiry into the Cost of the National Health Service under the Chairmanship of Mr. C. W. Guillebaud, which presented its report in November 1955 (Ministry of Health, 1956), recommended that the organization of the maternity services should be reviewed at an early date. As a direct result of this recommendation, the Cranbrook Committee was set up in 1956 and produced its report in 1959 (Ministry of Health, 1959). Whilst accepting that the existing tri-partite system must continue for some time to come, the Committee recommended that there should be a clearer definition of the responsibilities of the respective bodies providing the different parts of the service and greater coordina- tion and cooperation between them. The committee also recommended that provision should be made over the country as a whole for a sufficient number of maternity beds to allow for an average of $70 \%$ of institutional confinements, with the assumption that the normal period of stay after delivery would be 10 days. In the event, the institutional confinement rate was about $60 \%$ in 1958, reached the Cranbrook target figure of $70 \%$ in 1965, and has since increased still further. During this period, the average length of stay has fallen to well below the recommended period, partly as a result of the introduction of early discharge in some areas.

In association with this increase in the proportion of hospital births, there have also been changes in the type and extent of services provided by general practitioners and local authorities. The growing trend towards group practice conducted from health centre premises has permitted increasing specialization in general practice. There has been a marked increase in institutional facilities, which is accounted for almost entirely by the provision of additional general practitioner beds, the number of which has almost doubled since 1955 . The process of attachment of domiciliary midwives to group practices in local health authority areas has also developed, and by the end of 1966 , almost $10 \%$ of all domiciliary midwives were involved in this arrangement. General practitioners are replacing local health authority medical officers in staffing maternity and child health clinics and are providing ante- and post-natal care for their patients to an increasing extent. New district general hospitals are being built, incorporating general practitioner beds as part of a fully equipped and staffed maternity unit.

While all these changes have been presented as being logical and necessary developments of the existing system, it is desirable that their effect should be monitored and, as far as possible that the influence of each component should be identified. On the assumption that the standard of medical care is important, perinatal mortality provides an objective (if somewhat crude) measure of performance. For this reason, an analysis has been carried out of the 
data available on a national basis during the period 1960-69. This review is particularly relevant to the Peel Report on the future of the domiciliary midwife service which was published recently (Department of Health and Social Security, 1970).

\section{Birthweight and Perinatal Mortality}

Among the wide variety of factors which have been shown to be related to perinatal mortality, birth after too short a period of gestation and low birthweight for a given period of gestation are dominant. Although it would be desirable to base an epidemiological study upon a combination of data about gestational age and birthweight, it must be recognized that reliable information about gestation is notoriously difficult to obtain, particularly when recorded on a routine basis rather than as part of a special investigation. For this reason, information about birthweight, which is both closely related to gestation and is also of value in its own right, is of prime importance (Brimblecombe, Ashford and Fryer, 1968). In England and Wales, birthweight is not recorded as part of the standard registration procedures for live births. However, there is a statutory obligation for the medical attendant present at the birth to notify the local health authority of any late fetal death or live birth taking place within its boundaries. These birth notification documents include information about birthweight and other relevant factors and are aggregated to form the basis of annual returns (L.H.S. 27/1) by the local health authority to the Department of Health and Social Security. These annual summaries for all local authorities in England and Wales during the period 1956-69, together with the Registrar General's Statistical Reviews of England and Wales, form the basis of the results reported in this paper.

Analyses of the L.H.S. 27/1 data for the period 1956-65 have been reported elsewhere (Ashford, Fryer, and Brimblecombe, 1969; Ashford and Fryer, 1969). The main results of these studies may be summarized briefly as follows:

(1) there was a steady decrease in the proportion of low birthweight infants;

(2) there was a steady decrease in perinatal and neonatal mortality, which can be explained in part but not completely by corresponding changes in the birthweight distribution;

(3) there was a steady increase in the proportion of confinements taking place in hospital;

(4) there were considerable variations in birthweight distribution, perinatal and neonatal mortality and the proportion of hospital confinements between local authorities in different parts of the country and in the more urban and the more rural areas;
(5) there was no clear relationship between peri- $:$ natal and neonatal mortality and birthweight 3 on the one hand and the proportion of hospital $\stackrel{\circ}{\circ}$ confinements on the other in different local authorities.

Changes in Birthweight Distribution

Table I shows the proportion of live births and late fetal deaths in the four birthweight groups,

TABLE I

SECULAR TRENDS IN BIRTHWEIGHT DISTRIBUTION (RATE PER 1,000 TOTAL BIRTHS, ENGLAND AND WALES 1960-69)

\begin{tabular}{|c|c|c|c|c|c|}
\hline \multirow{2}{*}{ Year } & \multicolumn{5}{|c|}{ Birthweight (g) } \\
\hline & $<1,501$ & $1,501-2,000$ & $2,001-2,250$ & $2,251-2,500$ & $<2,501$ \\
\hline $\begin{array}{l}1960 \\
1961 \\
1962 \\
1963 \\
1964 \\
1965 \\
1966 \\
1967 \\
1968 \\
1969\end{array}$ & $\begin{array}{l}12.3 \\
12.5 \\
12.0 \\
11.8 \\
11.6 \\
10.9 \\
11.0 \\
10.9 \\
11.2 \\
10.9\end{array}$ & $\begin{array}{l}14.7 \\
14.7 \\
14.2 \\
14.4 \\
13.7 \\
13.4 \\
13.8 \\
13.7 \\
13.9 \\
13.8\end{array}$ & $\begin{array}{l}14.5 \\
14.5 \\
14.7 \\
14.8 \\
14.0 \\
13.7 \\
14.8 \\
14.6 \\
15.0 \\
15.5\end{array}$ & $\begin{array}{l}34.9 \\
34 \cdot 8 \\
34.8 \\
33 \cdot 5 \\
32.7 \\
32.6 \\
33.6 \\
33.8 \\
33.9 \\
34.2\end{array}$ & $\begin{array}{l}76 \cdot 4 \\
76 \cdot 5 \\
75 \cdot 7 \\
74 \cdot 5 \\
71 \cdot 9 \\
70 \cdot 5 \\
73 \cdot 2 \\
73 \cdot 0 \\
74 \cdot 0 \\
74 \cdot 4\end{array}$ \\
\hline
\end{tabular}

less than 1,501 g, 1,501-2,000 g, 2,001-2,250 g, and 2,251-2,500 $\mathrm{g}$ in England and Wales during the 18 years 1960-69 inclusive. The proportion of birth ? of $2,500 \mathrm{~g}$ or less fell from 76.4 per 1,000 in 1960 70.5 per 1,000 in 1965 . This tendency towards $\vec{a}$ decreasing proportion of low-weight births has persisted at least since 1957, but the results for $\cong$ 1966-69 show a clear reversal, the figure for $1969 \stackrel{\varnothing}{\varrho}$ being almost identical to that for 1963. The results $\overrightarrow{\vec{A}}$ for the separate birthweight groups show that the increase in low-weight births since 1965 is accounted for mainly by the groups 2,001-2,250 and 2,2512,500 g.

Table II shows the trends in the proportions of births of less than 2,501 $\mathrm{g}$ in the county boroughs and other local authorities. The increase in lowweight births since 1965 is apparent in both types of $\delta$

TABLE II

COMPARISON OF SECULAR TRENDS IN BIRTHWEIGHT DISTRIBUTION IN COUNTY BOROUGHS AND ALL OTHER $D$ LOCAL AUTHORITIES AND ALL OTHER D (BIRTHS OF WEIGHT LESS THAN 2,501 g PER 1,000 TOTAL 윽 BIRTHS, ENGLAND AND WALES 1960-69)

\begin{tabular}{c|c|c}
\hline Year & $\begin{array}{c}\text { County Boroughs } \\
\text { (including London) }\end{array}$ & $\begin{array}{c}\text { All Other Local } \\
\text { Authorities }\end{array}$ \\
\hline 1960 & $83 \cdot 7$ & $71 \cdot 9$ \\
1961 & $84 \cdot 3$ & $71 \cdot 7$ \\
1962 & 83.8 & $70 \cdot 7$ \\
1963 & $84 \cdot 2$ & $68 \cdot 8$ \\
1964 & $80 \cdot 4$ & 67.2 \\
1965 & $78 \cdot 0$ & 64.5 \\
1966 & $80 \cdot 4$ & $67 \cdot 2$ \\
1967 & 79.8 & $67 \cdot 3$ \\
1968 & $80 \cdot 8$ & 68.4 \\
1969 & $81 \cdot 2$ & 68.9 \\
\hline
\end{tabular}


local authority and the excess in the county boroughs has remained almost constant during the 10-year period. When the data are further subdivided in terms of the 11 standard regions used by the Registrar General before 1965, the same general trend of birthweight is apparent in the individual regions. There are, however, a few exceptions in that the proportion of low-weight births has continued to fall since 1965 in the county boroughs in the Northern, Eastern, and Welsh regions. The geographical variations between the different regions (Brimblecombe et al., 1968) still persist, the proportions of births of less than $2,501 \mathrm{~g}$ in 1969 varying between the extreme limits of 64.4 (county boroughs) and 64.0 (other local authorities) in the Eastern region to 88.2 (county boroughs) and 73.6 (other local authorities) in the North Western region.

\section{Changes in Mortality}

Table III shows the combined late fetal death and neonatal death rate in the four birthweight groups under $2,501 \mathrm{~g}$ and a single over $2,500 \mathrm{~g}$ birthweight group during the 10-year period (perinatal mortality rates are not available before 1963). There has been a steady decline in mortality in all the birthweight groups, the change in the second five years being virtually the same as during the first. When the results for county boroughs and other local authorities are considered separately a similar trend is apparent in both types of local authority (Table IV). The differences between the more urban and the more rural local authorities have increased between 1960 and 1969 , the higher mortality rates being recorded for the above 2,501 $\mathrm{g}$ birthweight group and the lower rates for the below 2,501 $\mathrm{g}$ birthweight group in the county boroughs. Reference to Tables I and III shows that the reduction of the overall neonatal mortality rate from 28.5 per 1,000 in 1965 to 25.0 per 1,000 in 1969 has been achieved in spite of an increase in the proportion of low-weight (and thus higher-risk) births.
TABLE IV

SECULAR TRENDS IN LATE FETAL DEATHS AND NEONATAL DEATHS PER 1,000 TOTAL BIRTHS IN COUNTY BOROUGHS AND ALL OTHER LOCAL AUTHORITIES, ENGLAND AND WALES, 1960-69

\begin{tabular}{|c|c|c|c|c|c|c|}
\hline \multirow{3}{*}{ Year } & \multirow{2}{*}{\multicolumn{3}{|c|}{$\begin{array}{c}\begin{array}{c}\text { County Boroughs } \\
\text { (inc. London) }\end{array} \\
\text { Birthweight (g) }\end{array}$}} & \multirow{2}{*}{\multicolumn{3}{|c|}{$\begin{array}{c}\begin{array}{c}\text { All Other Local } \\
\text { Authorities }\end{array} \\
\text { Birthweight (g) }\end{array}$}} \\
\hline & & & & & & \\
\hline & $<2,501$ & $>2,500$ & All & $<2,501$ & $>2,500$ & All \\
\hline $\begin{array}{l}1960 \\
1961 \\
1962 \\
1963 \\
1964 \\
1965 \\
1966 \\
1967 \\
1968 \\
1969\end{array}$ & $\begin{array}{l}254 \\
254 \\
243 \\
237 \\
236 \\
224 \\
219 \\
213 \\
206 \\
195\end{array}$ & $\begin{array}{l}16.4 \\
16.2 \\
15.1 \\
14.4 \\
14.0 \\
13.5 \\
12.7 \\
12.6 \\
12.6 \\
11.8\end{array}$ & $\begin{array}{l}36 \cdot 3 \\
36 \cdot 2 \\
34 \cdot 2 \\
33 \cdot 1 \\
31 \cdot 8 \\
29.9 \\
29 \cdot 3 \\
28 \cdot 6 \\
28 \cdot 2 \\
26 \cdot 7\end{array}$ & $\begin{array}{l}260 \\
257 \\
252 \\
248 \\
243 \\
234 \\
232 \\
228 \\
218 \\
208\end{array}$ & $\begin{array}{l}16.0 \\
14.5 \\
14.9 \\
13.5 \\
13.2 \\
13.0 \\
11.9 \\
11.2 \\
10.9 \\
10.0\end{array}$ & $\begin{array}{l}33.5 \\
31.9 \\
31.6 \\
29.6 \\
28.7 \\
27.3 \\
26.7 \\
25.8 \\
25.1 \\
23.7\end{array}$ \\
\hline
\end{tabular}

The combined late fetal death and neonatal mortality rates reflect a wide variety of influences, and further useful information may be obtained by considering the rates for late fetal death, and deaths following live birth within 24 hours, between 24 hours and 7 days, and between 7 and 28 days separately. The corresponding results for the five birthweight groups below $2,501 \mathrm{~g}$ are shown in Table $\mathrm{V}$, in which average figures for the years 1963-65 and 1967-69 are compared. These three-year averages have been examined to produce reasonable stability of the individual entries in the table. In all birthweight groups the rates for both late fetal deaths and deaths following live births within 24 hours have fallen. For deaths following live births between 24 hours and 7 days there has been an increase in rates for the less than 1,501 $\mathrm{g}$ birthweight groups and a decrease for the 1,501-2,500 g groups.

Furthermore, there has also been an increase in the rates for the less than $1,001 \mathrm{~g}$ and $1,501-2,250 \mathrm{~g}$ groups for deaths within 7 to 28 days. These results are consistent with a tendency for the more vulnerable infants to survive for a longer period and possibly to overcome the neonatal hazards to which they are vulnerable. It is interesting that the rates

TABLE III

SECULAR TRENDS IN LATE FETAL DEATHS AND NEONATAL DEATHS PER 1,000 BIRTHS, ENGLAND AND WALES 1960-69

\begin{tabular}{|c|c|c|c|c|c|c|c|}
\hline \multirow{2}{*}{ Year } & \multicolumn{7}{|c|}{ Weight Group (g) } \\
\hline & $<1,501$ & $1,501-2,000$ & $2,001-2,250$ & $2,251-2,500$ & $<2,501$ & Over 2,500 & All \\
\hline $\begin{array}{l}1960 \\
1961 \\
1962 \\
1963 \\
1964 \\
1965 \\
1966 \\
1967 \\
1968 \\
1969\end{array}$ & $\begin{array}{l}796 \\
784 \\
790 \\
769 \\
763 \\
756 \\
767 \\
749 \\
728 \\
730\end{array}$ & $\begin{array}{l}332 \\
331 \\
321 \\
320 \\
312 \\
303 \\
297 \\
290 \\
275 \\
267\end{array}$ & $\begin{array}{l}150 \\
146 \\
140 \\
130 \\
134 \\
126 \\
125 \\
122 \\
115 \\
106\end{array}$ & $\begin{array}{l}81 \cdot 4 \\
80 \cdot 3 \\
76 \cdot 8 \\
74 \cdot 1 \\
70 \cdot 1 \\
66 \cdot 0 \\
63 \cdot 0 \\
64 \cdot 0 \\
58 \cdot 4 \\
51 \cdot 8\end{array}$ & $\begin{array}{l}257 \\
256 \\
248 \\
243 \\
240 \\
229 \\
225 \\
221 \\
212 \\
202\end{array}$ & $\begin{array}{l}16.1 \\
15.2 \\
15.0 \\
13.8 \\
13.5 \\
13.2 \\
12.3 \\
11.8 \\
11.7 \\
10.8\end{array}$ & $\begin{array}{l}34.6 \\
33.6 \\
32.6 \\
30.9 \\
29 \cdot 8 \\
28 \cdot 5 \\
27 \cdot 9 \\
27 \cdot 1 \\
26.5 \\
25.0\end{array}$ \\
\hline
\end{tabular}


TABLE V

MOVEMENT IN MORTALITY-BIRTHWEIGHT RELATIONSHIP FOR ENGLAND AND WALES FROM 1963-65 TO 1967-69: $\$ RATE PER 1,000 TOTAL BIRTHS

\begin{tabular}{|c|c|c|c|c|c|}
\hline \multirow{2}{*}{ Mortality Grade } & \multicolumn{5}{|c|}{ Weight (g) } \\
\hline & $<1,001$ & $1,001-1,500$ & $1,501-2,000$ & $2,001-2,250$ & $2,251-2,500$ \\
\hline (1) Late fetal death & $\begin{array}{l}405 \\
389\end{array}$ & $\begin{array}{l}366 \\
336 \\
\end{array}$ & $\begin{array}{l}183 \\
157\end{array}$ & $\begin{array}{l}75 \cdot 2 \\
66 \cdot 4\end{array}$ & $\begin{array}{l}41 \cdot 6 \\
34 \cdot 5\end{array}$ \\
\hline (2) Death within 24 hours & $\begin{array}{l}387 \\
383\end{array}$ & $\begin{array}{l}195 \\
189\end{array}$ & $\begin{array}{l}72 \cdot 4 \\
65 \cdot 8\end{array}$ & $\begin{array}{l}27 \cdot 2 \\
24 \cdot 0\end{array}$ & $\begin{array}{l}13 \cdot 1 \\
10 \cdot 4\end{array}$ \\
\hline (3) Death within 24 hours-7 days & $\begin{array}{l}103 \\
108\end{array}$ & $\begin{array}{l}94 \cdot 6 \\
95 \cdot 6\end{array}$ & $\begin{array}{l}49 \cdot 3 \\
44 \cdot 3\end{array}$ & $\begin{array}{l}21 \cdot 8 \\
17 \cdot 7\end{array}$ & $\begin{array}{r}11 \cdot 2 \\
8 \cdot 9\end{array}$ \\
\hline (4) Death within 7-28 days & $\begin{array}{l}13 \cdot 3 \\
16 \cdot 6\end{array}$ & $\begin{array}{l}16 \cdot 5 \\
15 \cdot 6\end{array}$ & $\begin{array}{l}7 \cdot 7 \\
9 \cdot 9\end{array}$ & $\begin{array}{l}6 \cdot 1 \\
6 \cdot 2\end{array}$ & $\begin{array}{l}4 \cdot 3 \\
4 \cdot 3\end{array}$ \\
\hline$(1)+(2)$ & $\begin{array}{l}793 \\
772\end{array}$ & $\begin{array}{l}561 \\
525\end{array}$ & $\begin{array}{l}255 \\
223\end{array}$ & $\begin{array}{c}102 \\
90 \cdot 4\end{array}$ & $\begin{array}{l}54 \cdot 6 \\
44 \cdot 9\end{array}$ \\
\hline$\underset{\text { mortality })}{(1)+(3) \text { (perinatal }}$ & $\begin{array}{l}896 \\
880\end{array}$ & $\begin{array}{l}656 \\
621\end{array}$ & $\begin{array}{l}304 \\
268\end{array}$ & $\begin{array}{l}124 \\
108\end{array}$ & $\begin{array}{c}65 \cdot 8 \\
53 \cdot 9\end{array}$ \\
\hline $\begin{array}{l}(1)+(2)+(3) \\
+(4) \\
\text { (overall mortality) }\end{array}$ & $\begin{array}{l}909 \\
897\end{array}$ & $\begin{array}{l}672 \\
636\end{array}$ & $\begin{array}{l}312 \\
277\end{array}$ & $\begin{array}{l}130 \\
114\end{array}$ & $\begin{array}{l}70 \cdot 1 \\
58 \cdot 1\end{array}$ \\
\hline
\end{tabular}

Note: The first entry in each cell is the rate for 1963-65 and the second for 1967-69.

for deaths following live birth within seven days of birth did not decrease for the less than $1,001 \mathrm{~g}$ birthweight groups, although there were substantial decreases for the other birthweight groups. Reference to the overall mortality data in Table $V$ shows that there has been a substantial reduction in mortality in all birthweight groups above $1,000 \mathrm{~g}$, so much so that in spite of an increasing proportion of low-weight births since 1967 the mortality figures have continued to fall.

TABLE VI

MORTALITY RATES FOR BIRTHS OF LESS THAN $2,501 \mathrm{~g}$ PER 1,000 TOTAL BIRTHS, ENGLAND AND WALES 1960-69

\begin{tabular}{c|c|c|c}
\hline \multirow{2}{*}{ Year } & $\begin{array}{c}\text { Late Fetal } \\
\text { Death }\end{array}$ & \multicolumn{2}{|c}{ Death } \\
\cline { 3 - 4 } & 138 & Within 24 hr & $24 \mathrm{hr}-28$ days \\
\hline 1960 & 136 & $73 \cdot 7$ & $45 \cdot 6$ \\
1961 & 132 & 72.9 & 47.0 \\
1962 & 132 & $69 \cdot 9$ & 43.8 \\
1963 & 129 & $69 \cdot 4$ & 42.1 \\
1964 & 125 & $64 \cdot 0$ & 41.6 \\
1965 & 122 & 65.9 & 40.2 \\
1966 & 120 & $63 \cdot 1$ & 37.4 \\
1967 & 112 & $61 \cdot 5$ & 37.5 \\
1968 & 104 & 58.9 & 38.8 \\
1969 & & & 38.9 \\
\hline
\end{tabular}

Table VI shows the rates for late fetal deaths and deaths following live births within 24 hours and between 24 hours and 28 days for each year between 1960 and 1969 for infants weighing less than 2,501 $\mathrm{g}$ at birth. Although the rates for late fetal deaths and deaths within 24 hours of a live birth have fallen steadily year by year this trend holds for the deaths between 24 hours and 28 days up to 1966 only. Since that date the mortality rate has increased, a trend which is consistent with longer survival of infants who eventually die.

When the results were analysed in terms of the 11 standard regions the improvements in mortalit $\overrightarrow{0}$ rates noted in the combined data were present in a⿺辶 parts of the country. Particularly marked reduction. in mortality have taken place in both the count boroughs and other local authorities in both the Northern and South Wales regions and in the county boroughs in the Eastern region, these areas also showing a marked reduction in the proportion of low-weight births. On the other hand, the North Western and North Midland regions showed the least change. Throughout the 10-year period the mortality rates were higher in the north and west of the country than in the south and east. The range of variation in overall late fetal death and neonatal mortality rates in 1969 was from 32.5 (county boroughs) and 27.0 (other local authorities) in the North West to 20.3 (county boroughs) and 21.2 (other local authorities) in the Eastern region.

In view of the variations in birthweight distribution between different parts of England and Wales $\frac{D}{0}$ and from year to year between 1960 and 1969, it might be argued that the differences in overall or mortality should be assessed only after standardizing $N$ for birthweight distribution. Table VII compares $N$ the standardized mortality in the different regions $\omega$ and the two types of local authority between the periods 1963-65 and 1967-69, three-year intervals $\stackrel{0}{C}$ being taken to ensure stability of the individual results. For each period, the average for the country as a whole is 100 and it is clear that the relative position of the county boroughs has worsened in 
TABLE VII

OVERALL MORTALITY INDICES ADJUSTED FOR BIRTHWEIGHT BY REGION AND TYPE OF LOCAL AUTHORITY

\begin{tabular}{l|c|c}
\hline \multirow{2}{*}{ Region } & \multicolumn{2}{|c}{ Type of Local Authority } \\
\cline { 2 - 3 } & $\begin{array}{c}\text { County } \\
\text { Borough }\end{array}$ & $\begin{array}{c}\text { Other Local } \\
\text { Authorities }\end{array}$ \\
\hline 1. Northern & 105,105 & 106,100 \\
2. East and West Ridings & 103,107 & 107,101 \\
3. North West & 109,112 & 104,106 \\
4. North Midland & 99,103 & 100,99 \\
5. Midland & 101,102 & 100,102 \\
6. Eastern & 97,92 & 95,95 \\
7. London and South East & 91,95 & 96,92 \\
8. Southern & 94,94 & 92,90 \\
9. South Western & 93,96 & 100,96 \\
10. Wales I $\quad$ (South) & 95,107 & 114,112 \\
11. Wales II & - & 108,111 \\
$\quad$ (remainder) & - & \\
\hline
\end{tabular}

Note: The first figure refers to $1963-65$ and the second figure to 1967-69.

comparison with the other local authorities. The geographical variations noted in the crude mortality data persist even after correction for birthweight differences.

\section{Changes in the Pattern of Confinements}

The L.H.S. 27/1 reports upon which this analysis is based make specific reference to births taking place at home or in private nursing homes and in National Health Service institutions. The term 'institution' applies to all N.H.S. hospitals and no distinction is made between general practitioner units, hospitals with different standards of staffing and facilities or between general practitioner and consultant beds in consultant units. Table VIII shows the proportion of institutional births taking place in county boroughs and other local authorities

\section{TABLE VIII}

SECULAR TRENDS IN TERMS OF PLACE OF CONFINEMENT BY TYPE OF LOCAL AUTHORITY : INSTITUTIONAL BIRTHS PER 1,000 TOTAL BIRTHS. ENGLAND AND WALES, 1960-69

(a) All births

\begin{tabular}{|c|c|c|c|c|c|c|c|c|c|c|}
\hline \multirow{2}{*}{ Population } & \multicolumn{10}{|c|}{ Year } \\
\hline & 1960 & 1961 & 1962 & 1963 & 1964 & 1965 & 1966 & 1967 & 1968 & $\overline{1969}$ \\
\hline $\begin{array}{l}\text { County } \\
\text { boroughs } \\
\text { Remainder }\end{array}$ & $\begin{array}{l}661 \\
644 \\
\end{array}$ & $\begin{array}{l}674 \\
651\end{array}$ & $\begin{array}{l}673 \\
656\end{array}$ & $\begin{array}{l}697 \\
677\end{array}$ & \begin{tabular}{|l|}
713 \\
696 \\
\end{tabular} & \begin{tabular}{|l|}
743 \\
713
\end{tabular} & $\begin{array}{l}767 \\
738\end{array}$ & \begin{tabular}{|l|}
790 \\
769
\end{tabular} & \begin{tabular}{|l|}
819 \\
797
\end{tabular} & $\begin{array}{l}849 \\
827\end{array}$ \\
\hline Total & $\overline{650}$ & $\overline{660}$ & $\overline{662}$ & $\overline{684}$ & $\overline{702}$ & $\overline{727}$ & 751 & 778 & 807 & 837 \\
\hline
\end{tabular}

(b) Births weighing $<2,501 \mathrm{~g}$

\begin{tabular}{|c|c|c|c|c|c|c|c|c|c|c|}
\hline \multirow{2}{*}{ Population } & \multicolumn{10}{|c|}{ Year } \\
\hline & $\overline{1960}$ & 1961 & 1962 & 1963 & $\mid 1964$ & 1965 & 1966 & 1967 & 1968 & 1969 \\
\hline $\begin{array}{l}\text { County } \\
\text { boroughs } \\
\text { Remainder }\end{array}$ & $\begin{array}{l}786 \\
778\end{array}$ & $\begin{array}{l}802 \\
789\end{array}$ & $\begin{array}{l}806 \\
803\end{array}$ & $\begin{array}{l}822 \\
828\end{array}$ & $\begin{array}{l}841 \\
841\end{array}$ & $\begin{array}{l}865 \\
858\end{array}$ & $\begin{array}{l}877 \\
874\end{array}$ & $\begin{array}{l}891 \\
892 \\
\end{array}$ & $\begin{array}{l}904 \\
907\end{array}$ & $\begin{array}{l}922 \\
922\end{array}$ \\
\hline Total & 781 & 794 & 804 & 825 & 841 & 861 & 876 & 892 & 905 & 922 \\
\hline
\end{tabular}

during each successive year. The proportion of institutional births has increased year by year from 661 to 849 per 1,000 total births in the county boroughs and from 644 to 827 in the other local authorities. The corresponding figures for infants of less than 2,501 $\mathrm{g}$ birthweight are 786 to 922 for county boroughs and 778 to 922 for other local authorities. The results for the 11 standard regions, which cover the three-year periods 1963-65 and 1967-69, show considerable diversity (Table IX), and it is clear that policies laid down nationally are being interpreted in different ways in different parts of the country. In general, the lowest proportion of institutional confinements was recorded in the Eastern and Midland regions and the highest in London and the South East and South Wales. During the period 1967-69, the proportions of all institutional confinement varied from 675 to 864 in county boroughs and from 723 to 930 in the other local authorities.

TABLE IX

TRENDS IN PLACE OF CONFINEMENT BY REGION AND TYPE OF LOCAL AUTHORITY: INSTITUTIONAL BIRTHS PER 1,000 TOTAL BIRTHS

\begin{tabular}{|c|c|c|c|c|}
\hline \multirow{3}{*}{ Region } & \multicolumn{4}{|c|}{ Type of Local Authority } \\
\hline & \multicolumn{2}{|c|}{$\begin{array}{c}\text { County } \\
\text { Boroughs }\end{array}$} & \multicolumn{2}{|c|}{$\begin{array}{l}\text { Other Local } \\
\text { Authorities }\end{array}$} \\
\hline & $1963-65$ & $1967-69$ & $1963-65$ & $1967-69$ \\
\hline $\begin{array}{l}\text { 1. Northern } \\
\text { 2. East and West Ridings } \\
\text { 3. North Western } \\
\text { 4. North Midland } \\
\text { 5. Midland } \\
\text { 6. Eastern } \\
\text { 7. London and South East } \\
\text { 8. Southern } \\
\text { 9. South Western } \\
\text { 10. Wales I (South) } \\
\text { 11. Wales II (Remainder) }\end{array}$ & $\begin{array}{l}666 \\
678 \\
712 \\
635 \\
656 \\
642 \\
812 \\
652 \\
733 \\
750 \\
\end{array}$ & $\begin{array}{l}790 \\
791 \\
830 \\
771 \\
770 \\
675 \\
864 \\
777 \\
831 \\
859 \\
\end{array}$ & $\begin{array}{l}722 \\
691 \\
719 \\
662 \\
626 \\
624 \\
723 \\
738 \\
716 \\
718 \\
858\end{array}$ & $\begin{array}{l}842 \\
816 \\
810 \\
757 \\
743 \\
723 \\
790 \\
825 \\
842 \\
864 \\
930\end{array}$ \\
\hline All regions & 718 & 819 & 695 & 798 \\
\hline
\end{tabular}

On the grounds that the special facilities which only well-staffed and equipped hospitals can provide should be allocated to the higher risk confinements, it might be expected that the proportion of institutional births should be substantially greater among low birthweight infants than in the population as a whole. Reference to Table X confirms this and shows that the variation in confinement rates between different regions is less than for all births. It is, however, interesting that during the period 1967-69 when the overall institutional confinement rate was about 800 per 1,000 , as many as 1 in 10 of the low-weight births took place at home or in private nursing homes.

A key question as regards policies for maternity services is whether above-average proportions of institutional births are accompanied by correspond- 
TABLE X

TREND IN PLACE OF CONFINEMENT FOR LOW-WEIGHT BIRTHS $(<2501 \mathrm{~g})$ BY REGION AND TYPE OF LOCAL AUTHORITY: INSTITUTIONAL BIRTHS PER 1,000 TOTAL BIRTHS

\begin{tabular}{l|c|c|c|c}
\hline \multicolumn{1}{c|}{ Region } & \multicolumn{3}{|c|}{ Type of Local Authority } \\
\cline { 2 - 4 } & \multicolumn{2}{|c|}{$\begin{array}{c}\text { County } \\
\text { Boroughs }\end{array}$} & \multicolumn{2}{c}{$\begin{array}{c}\text { Other Local } \\
\text { Authorities }\end{array}$} \\
\hline & $1963-65$ & $1967-69$ & $1963-65$ & $1967-69$ \\
\hline 1. Northern & 793 & 877 & 815 & 921 \\
2. East and West Ridings & 829 & 892 & 834 & 911 \\
3. North Western & 840 & 899 & 851 & 916 \\
4. North Midland & 814 & 879 & 810 & 904 \\
5. Midland & 803 & 880 & 804 & 878 \\
6. Eastern & 787 & 848 & 809 & 873 \\
7. London and South East & 905 & 938 & 877 & 907 \\
8. Southern & 765 & 868 & 887 & 923 \\
9. South Western & 873 & 919 & 850 & 925 \\
10. Wales I (South) & 865 & 937 & 861 & 921 \\
11. Wales II (remainder) & - & - & 913 & 924 \\
\hline All regions & 843 & 906 & 842 & 907 \\
\end{tabular}

ing below-average mortality rates. In order to get some answer to this question the combined late fetal death and neonatal mortality rates for each local authority were adjusted for birthweight distribution for each successive year between 1956 and 1969. These standardized mortality rates were then compared with the corresponding proportions of hospital confinements, which were also standardized to an average of 100 for the country as a whole, for the particular year. In order to determine whether the proportions of hospital births are related to the standardized mortality rates in the local authorities

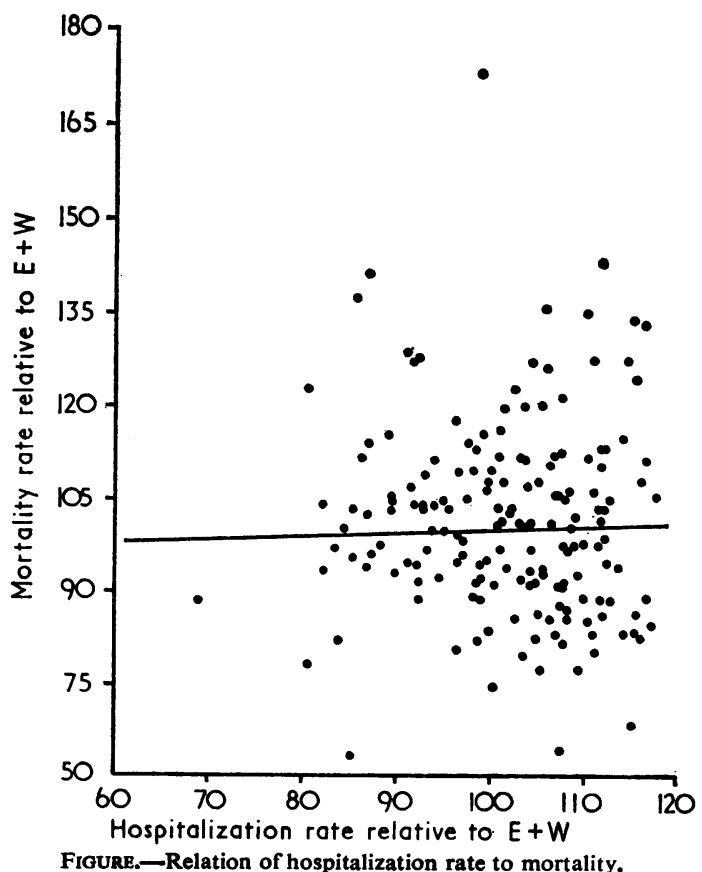

scatter diagrams were plotted. An example is given in the Figure which refers to the 173 local authorities existing in 1969 and to all birthweights. The ? results show a very wide spread. In order to deter- $\overrightarrow{\vec{D}}$ mine whether or not a linear trend exists, a re- $\frac{\vec{\sigma}}{0}$ gression line, weighted to take account of the $\frac{C}{0}$ differences in the total numbers of births, was $\overline{\bar{N}}$ fitted to the data. The slope of the fitted regression $\widehat{\nabla}$ line indicates the linear trend of the relationship. A negative slope indicates that as the proportion of $\mathrm{c}$ hospital births increases, the mortality decreases, $\overrightarrow{0}$ whereas a positive slope indicates the reverse. $\vec{A}$ Similar calculations were carried out for the three $\vec{\omega}$ birthweight groups, less than $1,501 \mathrm{~g}$, less than $2,501 \mathrm{~g}$, greater than 2,500 $\mathrm{g}$ and for all birthweights. These $\stackrel{9}{子}$ analyses were carried out for the complete set of data, for county boroughs and other local authorities separately, and for each type of local authority $\overrightarrow{-}$ in each of the 11 standard regions separately.

The results obtained for the complete set of data for each successive year are summarized in Table

\section{TABLE XI}

ESTIMATED REGRESSION COEFFICIENT OF ADJUSTED MORTALITY RATE ON STANDARDIZED HOSPITAIIZATION RATE BY BIRTHWEIGHT FOR ALL LOCAL AUTHORITIES IN ENGLAND AND WALES 1956-69

\begin{tabular}{|c|c|c|c|c|}
\hline \multirow{2}{*}{ Year } & \multicolumn{4}{|c|}{ Birthweight (g) } \\
\hline & $<1,501$ & $<2,501$ & $>2,500$ & All Weights \\
\hline 1956 & $\begin{array}{c}-0.114 \\
(-1.075)\end{array}$ & $\begin{array}{c}-0.189 \\
(-2.675)\end{array}$ & $\begin{array}{c}-0.334 \\
(-3.505)\end{array}$ & $\begin{array}{c}-0.241 \\
(-4.607)\end{array}$ \\
\hline 1957 & $\begin{array}{c}-0.037 \\
(-0.484)\end{array}$ & $\begin{array}{c}-0.161 \\
(-2.436)\end{array}$ & $\begin{array}{c}-0.355 \\
(-3.632)\end{array}$ & $\begin{array}{c}-0.228 \\
(-4 \cdot 382)\end{array}$ \\
\hline 1958 & $\begin{array}{c}-0.148 \\
(-2.037) \\
\end{array}$ & $\begin{array}{c}0 \cdot 107 \\
(1 \cdot 300)\end{array}$ & $\begin{array}{c}-0.268 \\
(-2.458)\end{array}$ & $\begin{array}{c}-0.085 \\
(-1.413)\end{array}$ \\
\hline 1959 & $\begin{array}{c}-0.068 \\
(-0.812)\end{array}$ & $\begin{array}{c}-0.096 \\
(-1.131)\end{array}$ & $\begin{array}{c}-0.072 \\
(-0.634)\end{array}$ & $\begin{array}{c}-0 \cdot 100 \\
(-1 \cdot 578)\end{array}$ \\
\hline 1960 & $\begin{array}{c}-0.132 \\
(-1.438)\end{array}$ & $\begin{array}{c}-0.171 \\
(-1.749)\end{array}$ & $\begin{array}{c}-0.133 \\
(-1.294)\end{array}$ & $\begin{array}{c}-0 \cdot 138 \\
(-2 \cdot 374)\end{array}$ \\
\hline 1961 & $\begin{array}{c}-0.158 \\
(-1.567)\end{array}$ & $\begin{array}{c}-0.174 \\
(-1.496)\end{array}$ & $\begin{array}{c}-0.111 \\
(-0.824)\end{array}$ & $\begin{array}{c}-0.151 \\
(-2 \cdot 222)\end{array}$ \\
\hline 1962 & $\begin{array}{c}-0.376 \\
(-3.388)\end{array}$ & $\begin{array}{c}-0.337 \\
(-3 \cdot 260)\end{array}$ & $\begin{array}{c}-0.138 \\
(-1.054)\end{array}$ & $\begin{array}{c}-0.161 \\
(-2 \cdot 390)\end{array}$ \\
\hline 1963 & $\begin{array}{c}-0.095 \\
(-0.816)\end{array}$ & $\begin{array}{c}-0.135 \\
(-1.173)\end{array}$ & $\begin{array}{c}-0.164 \\
(-1 \cdot 333)\end{array}$ & $\begin{array}{c}-0.137 \\
(-1.948)\end{array}$ \\
\hline 1964 & $\begin{array}{c}-0.113 \\
(-0.709)\end{array}$ & $\begin{array}{c}-0.313 \\
(-2.461)\end{array}$ & $\begin{array}{c}0.072 \\
(0.558)\end{array}$ & $\begin{array}{c}-0.101 \\
(-1 \cdot 316)\end{array}$ \\
\hline 1965 & $\begin{array}{c}0.021 \\
(0.134)\end{array}$ & $\begin{array}{r}-0.146 \\
(-1.094)\end{array}$ & $\begin{array}{c}0.038 \\
(0.322)\end{array}$ & $\begin{array}{c}-0.080 \\
(-1 \cdot 164)\end{array}$ \\
\hline 1966 & $\begin{array}{c}-0.118 \\
(-0.773)\end{array}$ & $\begin{array}{c}-0.307 \\
(-2.068)\end{array}$ & $\begin{array}{c}0.131 \\
(0.862)\end{array}$ & $\begin{array}{c}-0.026 \\
(-0.339)\end{array}$ \\
\hline 1967 & $\begin{array}{l}0.012 \\
(0.071) \\
\end{array}$ & $\begin{array}{c}-0.005 \\
(-0.030)\end{array}$ & $\begin{array}{c}-0.054 \\
(-0.336) \\
\end{array}$ & $\begin{array}{c}-0.093 \\
(-1 \cdot 141)\end{array}$ \\
\hline 1968 & $\begin{array}{c}0.001 \\
(0.004)\end{array}$ & $\begin{array}{c}0.008 \\
(0.045) \\
\end{array}$ & $\begin{array}{c}0.534 \\
(2.696)\end{array}$ & $\begin{array}{c}0.165 \\
(1.708) \\
\end{array}$ \\
\hline 1969 & $\begin{array}{c}-0.337 \\
(-2.038)\end{array}$ & $\begin{array}{c}-0.377 \\
(-1.607)\end{array}$ & $\begin{array}{c}0.359 \\
(1.455)\end{array}$ & $\begin{array}{c}0.044 \\
(0.379)\end{array}$ \\
\hline
\end{tabular}

Note: The ratio of the estimate to its estimated standard error is given in parentheses. 
XI. For all birthweights the slopes of the regression lines are negative between 1956 and 1967 but tend to decrease in magnitude in relation to their estimated standard error with the passage of time. In 1968 and 1969, however, the coefficients are small and positive. These results suggest that between 1956 and 1967 the local authorities with the higher proportions of institutional births had the lower mortality rates. During this period the proportion of hospital births increased from 646 per 1,000 to 778. Following the further increase of hospital births in 1968 and 1969, however, this trend was reversed and in 1969 the local authorities with the higher proportions of hospital births also tended to have the higher mortality rates. The separate analyses for the three birthweight groups show apparently contradictory trends. Since 1964, five of the six regression coefficients for infants weighing more than $2,500 \mathrm{~g}$ are positive, the largest occurring in 1968 and 1969. The corresponding results for infants of birthweight less than $2,501 \mathrm{~g}$, on the other hand, are almost all negative, the single (very small) positive coefficient occurring in 1968, whilst those for the much smaller number of infants of less than $1,501 \mathrm{~g}$ birthweight show no clear trend. When urban and rural areas are separated similar patterns are found, although there is a tendency for the lower weight births in the county boroughs to show more negative coefficients. The analyses for the individual regions for the most part follow a similar pattern to the aggregated data for each type of authority but there are some anomalies. For example, when all weights are taken together there is a much stronger tendency towards negative regression coefficients in London and the South East than there is in the North Midlands.

\section{COMMENT}

The analysis of the data for the past decade reveals a clear distinction between the first and second five-year periods. In general, the trends established during the late 1950 s persisted until about 1966 . The decline in the proportion of low-weight births and the increasing proportion of hospital confinements are matched by decreasing rates of late fetal death and neonatal mortality. Local authority areas with the higher proportion of hospital confinements tended to have the lower mortality rates. The second half of the decade produced a reversal of the trends in birthweight distribution, although the reductions in mortality continued. The proportion of hospital confinements continued to increase, but for births of more than $2,500 \mathrm{~g}$ the local authorities with the higher hospitalization rates no longer tended to have the lower mortality rates.
The reasons for the recent growth in the proportion of low-weight births are by no means clear. While increasing emphasis has been given in the clinical management of mothers during pregnancy to the avoidance of undue gain in weight, this change in medical fashion is unlikely to have had any substantial effect in the part of the birthweight distribution below 2,001 g. A similar remark applies to the growth in the proportion of induced births during the decade, although the proportion of births in the weight groups between 2,000 and 3,999 $\mathrm{g}$ may have increased as a result. Smoking in pregnancy is known to be associated with a reduction in birthweight, but the medical profession has tended to advise expectant mothers to give up the habit and there is no general evidence of a substantial increase in smoking among women of child-bearing age. Experience in Hungary (Czeizel, Bognár, Tusnady and Révész, 1970) where abortion has been legalized for many years, suggests that this practice, if sufficiently widespread, may ultimately result in an increased proportion of low-weight births, but it is likely that the change in the legal position in England and Wales came too late to produce any significant effect. Increase in illegitimacy offers another possible explanation, but the strong upward trend during the early 1960s has recently slowed down markedly.

Although births to immigrant parents may account for an increasing proportion of the total, any possible effect of this factor would be confined to specific parts of the country. Other possible contributory factors include the tendency for mothers to marry earlier in recent years, the absence of any general increase in standards of living since 1965 coupled with the possible decrease in real income among the poorer section of the community, and the probable growth in the consumption of drugs by medication, but none of these is in itself likely to account for a major part of the observed change in birthweight distribution. In our opinion, the explanation is likely to involve an accumulation of many small effects rather than any single dominant factor.

As regards future policy for the maternity services, the observation that since 1964 relatively high rates of institutional confinements for infants weighing more than 2,500 $\mathrm{g}$ at birth are no longer associated with relatively low mortality rates suggests that a more selective allocation of resources might be desirable in an attempt not only to reduce still further infant mortality, but also to reduce the incidence of handicap at a later age. As in other parts of the health care field, the real problem in the provision of maternity services is to achieve the best possible results under the constraints to which the system is 
subject. Our evidence supports the view that this optimum solution is more likely to be achieved by an effective policy of selection of high-risk confinements for the higher and more expensive standards of care than by spreading the available resources more thinly in an attempt to increase the proportion of institutional births. Using the criterion of minimizing mortality, the present analysis suggests that any further increase in the proportion of such confinements might even be counter-productive under existing conditions. However, as mortality rates have fallen the nature of the problem has changed, in the sense that greater weight must now be given to the concept of intact survival, rather than merely to the avoidance of infant death. Unfortunately, these possibly more realistic criteria for success are also more difficult to measure in an accurate and reproducible way. While it may be asserted on general grounds that effective antenatal paediatrics and the highest possible standards of care during delivery call for hospital facilities, there is no objective evidence that more than a small proportion of the confinements currently taking place in institutions enjoy services substantially better than could be provided in the mother's own home by an effective domiciliary service. Indeed, unless the hospital is adequately staffed and equipped and efficiently managed a false sense of security may be engendered.

What is required for the formulation of an effective policy for the future is a study in both economic and social as well as purely medical terms of the costs and benefits of various alternative policies for the development of the maternity services. The argument, which is often used, that because every confinement carries a possible and unpredictable risk, hospital care (and, by implication, the highest possible standards of hospital care) should be provided on a general basis is worthy of very critical examination. The same general assumption applies to a considerable number of medical conditions, for some of which the consequences of possible complications are equally severe. The allocation of resources to medical care generally must involve the balancing of a very wide variety of needs of this kind and if this is done it does not seem very likely that the maternity field would commend itself as a candidate for such very special treatment.

The operational aspects of the current policies must also be considered. At the present time the proportion of domiciliary confinements has fallen so low that in some areas, and particularly in rural areas, the maintenance of an effective and efficient domiciliary service presents severe difficulties. While the coming unification of the health services should assist with the integration of hospital and domiciliary services, if any provision at all is to be made for home confinements it is essential that the level of use and work content of the domiciliary service does not fall below a minimum level. Observation of the situation in particular parts of the country suggests that this limit may now have been reached.

If a more effective policy for the development of the maternity services is to be applied, adequate information about the performance of the system is essential.

As far as the choice of cases for hospital care is concerned, at the present time although more than $90 \%$ of confinements are in hospital, substantial numbers of low-weight births still take place at home. This is to some extent a result of inadequate selection procedures and, in consequence, the LHS $27 / 1$ reports show that about one-fifth of the lowweight infants born at home are subsequently transferred to hospital. However, these returns do not refer to the unknown number of infants transferred to hospital for special care from general practitioner units or other hospitals. This particular deficiency in the recorded data emphasizes the fact that the LHS $27 / 1$ report is providing a progressively les adequate means of monitoring the maternity sero vices. What is now required is a complete revision of the content of this return and of the individual birth notification documents upon which it is based. In particular a distinction should now be made between the different classes of institutional care provided within the NHS and some account should be taken of the basis for selection of home confinements.

Finally, the limitations of the present analysis as a means for providing a comprehensive monitoring service of the maternity care system must be recognized. In particular, the existing wide variations in mortality between different local authorities reflect many factors, including some such as environmental conditions, standard of education, income and family background, which are probably at least as important determinants of mortality as the place of confinement. Indeed, the authors are currently attempting to assess these variations in terms of the data available on a local authority basis, in order to isolate the effects of differences in standards of medical care. Nevertheless, the fact that a high degree of negative association between mortality and the proportion of institutional confinement has become progressively less strong during the late 1950 s and early 1960 s and has turned into a positive association during recent years, suggests very strongly that the increased expenditure associated 
with this trend is perhaps not producing the best possible effect.

\section{SUMMARY}

This study is based mainly on the annual returns made by each local authority, which show mortality in terms of birthweight distribution and place of confinement. The proportion of low-weight births decreased year by year between 1957 and 1965 . There was then a reversal of the trend, the birthweight distribution for 1969 being almost identical with that for 1963. This pattern was present in both urban and rural areas in almost all parts of the country.

There has been a steady decline in perinatal and neonatal mortality throughout the whole range of birthweights, and overall mortality has declined year by year, in spite of some unfavourable changes in birthweight distribution. This improvement has occurred in both urban and rural areas in all parts of England and Wales. The differences between the more urban and the more rural areas have increased between 1960 and 1969, the higher mortality rates being recorded for the above $2,500 \mathrm{~g}$ birthweight group and the lower rates for the below 2,501 $\mathrm{g}$ birthweight group in the more urban areas. The mortality rates have been sub-divided in terms of time of death, and the results show a general tendency for the more vulnerable infants to live for longer periods and possibly to survive the neonatal hazards to which they are particularly prone. When the mortality data were standardized for birthweight distribution it was found that the relative position of the county boroughs has worsened in comparison with other local authorities since 1960.

The proportion of births taking place in institutions rose from just over 650 to about 850 per 1,000 total births in the county boroughs and from just under 650 to about 825 in the other local authorities. There was a considerable variation in the proportion of institutional confinements in different local authorities even during the same year. There was a tendency for the local authorities with the higher rates of institutional confinement to have the lower mortality rates until about 1967, although the strength of the relationship decreased year by year. Since 1967 the trend was reversed and local authorities with the higher institutional confinement rates tended to have the higher mortality.
This apparently adverse effect of higher institutional confinement rates is associated mainly with the above $2,500 \mathrm{~g}$ birthweight group.

It is suggested that a further concentration of resources upon the more vulnerable sections of the population would be desirable. The inadequacy of existing statistical procedures for monitoring the performance of the maternity services is emphasized.

The authors are obliged to Mr M. D. Macdonald for assistance with the processing and analysis of the basic data. This work forms part of the research programme of the Institute of Biometry and Community Medicine of the University of Exeter.

\section{REFERENCES}

ASHFord, J. R., and Fryer, J. G. (1970). Perinatal mortality, birth weight and place of confinement in England and Wales 1956-65. In In the Beginning. Studies of Maternity Services, edited by G. McLachlan and R. Shegog, Chapter 6, pp. 133-150. Oxford University Press, London.

,-- , and Brimblecombe, F. S. W. (1969). Secular trends in late foetal deaths, neonatal mortality, and birth weight in England and Wales, 1956-65. Brit. J. prev. soc. Med., 23, 154.

Brimblecombe, F. S. W., Ashford, J. R., and Fryer, J. G. (1968). The significance of low birth weight in perinatal mortality. A study of variations within England and Wales. Brit. J. prev. soc. Med., 22, 27.

Czeizel, A., Bognár Z., Tusnády, G., and Révész, P. (1970). Changes in mean birth weight and proportion of low-weight births in Hungary. Brit. J. prev. soc. Med., 24, 146.

Department of Health and Social Security Welsh Office, Central Health Services Council (1970). Domiciliary midivifery and maternity bed needs. Report of a sub-committee of the Standing Maternity and Midwifery Advisory Committee (Peel Report). H.M.S.O., London.

Hunt, E. P., and Goldstern, S. M. (1964). Trends in Infant and Childhood Mortality, 1961. Children's Bureau Statistical Series, No. 76. U.S. Department of Health, Education and Welfare.

Ministry OF Health (1956). Report of the Committee of Enquiry into the Cost of the National Health Service (Guillebaud Committee). Cmd. 9663. H.M.S.O., London.

Ministry of Health (1959). Report of the Maternity Services Committee (Cranbrook Report). H.M.S.O., London. 